\title{
The Diversity and Productivity of Indigenous Forage in Former Limestone Mining Quarry in Karst Mountain of Southern Gombong, Central Java Indonesia
}

\author{
Doso Sarwanto ${ }^{1)^{*}}$ and Caribu Hadi Prayitno ${ }^{2)}$ \\ 1)Faculty of Animal Husbandry, Wijayakusuma University, Jl. Raya Beji Karangsalam Purwokerto 53152 Indonesia \\ 2) Faculty of Animal Science, Jenderal Soedirman University, Jl. dr. Suparno Purwokerto 53123 Indonesia \\ *Corresponding author email: dososarwanto@gmail.com
}

\begin{abstract}
Indonesia is a country that has a lot of limestone mountains, covering 15.4 million hectares. Limestone mountains have strategic functions as limestone is used as building materials and as raw material in cement industry. Therefore, limestone mining quarry in various areas of limestone mountains in Indonesia is increasingly widespread. The biggest negative impact of limestone mining is the formed open land which is abandoned and unutilized. Changes in the ecosystem will lead to the reduced levels of diversity and productivity of indigenous forage which will ultimately reduce the performance and development of ruminants livestock kept by farmers in the mountainous region of limestone. This study aims to determine the diversity and productivity of indigenous forage on former limestone mining quarry in limestone mountains of southern Gombong. The research was conducted through survey by identifying and measuring the forage production of sample plots assigned purposively. Location of the study was divided into three categories, mild, moderate and heavy mining. Results showed that soil fertility levels in open fields of former limestone mining in southern Gombong mountains are low with total $\mathrm{N}$ content of $0.049-0.141 \%$, total $\mathrm{P}_{2} \mathrm{O}_{5}$ of $0.067-0.133 \%$ and total $\mathrm{K}_{2} \mathrm{O}$ of $0.086-0.100 \%$. The diversity of indigenous forage on mild mining was more diverse than that of moderate and heavy mining, i.e. 13 species comprising 7 grass species, 2 legumes species, and 4 species of shrubs. The most dominant species in all mining categories are Cynodon dactylon, Imperata cylindrica, Ageratum conyzoides and Mikania micrantha. The results also showed that in the open land of mild mining had the highest production of fresh and dry matter compared to that of moderate and severe mining.
\end{abstract}

Key words: diversity, indigenous forage, limestone mountains

Abstrak. Indonesia merupakan salah satu negara yang mempunyai banyak pegunungan kapur, luasnya mencapai 15,4 juta hektar. Pegunungan kapur memiliki fungsi yang sangat strategis karena batuan kapur banyak dimanfaatkan sebagai bahan bangunan dan bahan pembuatan semen. Oleh karena itu usaha penambangan batu kapur di berbagai wilayah pegunungan kapur di Indonesia semakin berkembang luas. Dampak negatif terbesar dari usaha penambangan batu kapur adalah terbentuknya lahan terbuka yang terlantar dan tidak didayagunakan. Perubahan ekosistem tersebut akan menyebabkan menurunnya tingkat keragaman dan produktivitas hijauan pakan indigenous yang pada akhirnya akan menurunkan tingkat kinerja dan perkembangan ternak ruminansia yang dipelihara oleh peternak di wilayah pegunungan kapur. Penelitian ini bertujuan untuk mengetahui keragaman dan produktivitas hijauan pakan indigenous pada lahan bekas penambangan kapur di pegunungan kapur Gombong selatan. Metode yang digunakan adalah metode survei dengan melakukan inventarisasi dan pengukuran produksi melalui petak contoh secara purposive. Lokasi penelitian terbagi dalam tiga katagori yaitu penambangan ringan, sedang dan berat. Hasil penelitian menunjukkan bahwa tingkat kesuburan tanah di lahan terbuka bekas penambangan di pegunungan kapur Gombong selatan tergolong rendah dengan kandungan $\mathrm{N}$ total $0,049-0,141 \%, \mathrm{P}_{2} \mathrm{O}_{5}$ total 0,067 $-0,133 \%$ dan $\mathrm{K}_{2} \mathrm{O}$ total $0,086-0,100 \%$. Keragaman hijauan pakan indigenous pada penambangan sedang mempunyai keragaman lebih tinggi dari penambangan ringan dan berat yaitu 13 spesies yang terdiri 7 spesies rumput, 2 spesies legum, dan 4 spesies perdu. Spesies yang paling dominan pada semua katagori penambangan adalah Cynodon dactylon, Imperata cylindrica, Ageratum conyzoides dan Mikania micrantha. Hasil penelitian juga menunjukkan bahwa di lahan terbuka bekas penambangan ringan mempunyai produksi segar dan bahan kering yang paling tinggi dibandingkan penambangan sedang dan berat.

Kata Kunci : keragaman, hijauan pakan indigenous, pegunungan kapur 


\section{Introduction}

Indonesia is a country in the world that has a lot of limestone mountains, covering about 15.4 million hectares, which is $8.2 \%$ of the land area of the country. Limestone mountains have strategic functions as the limestone are widely used for building materials, bleach, handicrafts, marbles and as a mixture of cement paste. Besides, limestone mountain is a landscape that has important economical value to the environment such as water resources, biodiversity and tourism. The demand for limestone is increasing from year to year in line with the better development in Indonesia. Therefore, limestone mining in different areas of limestone mountains in Indonesia is increasingly widespread.

The biggest negative impact of limestone mining was the formation of open land which is abandoned and unutilized. Such conditions can damage the environment in the form of landscape alteration, changes in hydrology, as well as changes of plant and animal habitats. The open land due to limestone mining will though be widespread from time to time which will result also in changes in the ecosystem of limestone mountains. Changes in the ecosystem will lead to reduced levels of diversity and productivity of indigenous forage which will ultimately decrease the performance level and development of ruminants livestock such as cows and goats which are widely raised by farmers in the limestone mountainous regions.

The diversity and productivity of indigenous forage on open land of former limestone mining are affected by its soil fertility. Limestone soil or Mediterranean soil is the soil formed from rotted limestone rocks and has a $\mathrm{pH}$ of 5.5 - 8. Limestone soils have poor essential nutrients such as nitrogen, phosphate and potassium thus the soils are infertile for plants. However, limestone soils still contain high levels of macro nutrients such as calcium
(Ca) and magnesium ( $\mathrm{Mg}$ ) required for the development of the juvenile tissues. On the other hand, soils with high calcium (Ca) will cause plants to suffer deficiencies from Iron $(\mathrm{Fe})$, Manganese (Mn), Zinc ( $\mathrm{Zn})$ and Copper (Cu). Deficiencies of these elements can affect the diversity and productivity of indigenous forage in limestone mountains. Research conducted by Bojkovski et al. (2014) in the limestone mountainous region of Slovenia showed that the plants do not easily grow in the region except some grass and shrubs. As most of the open land surrounding limestone mountains is covered with grasses and shrubs, goats are more predominant to grass than sheep. This is because goats have better ability to utilize and digest various types of forage, especially in the mornings.

One of limestone mountains in Indonesia is southern Gombong limestone mountain located in Kebumen Regency of Central Java Province. Limestone mountain in southern Gombong has an area about 7,000 hectares stretching from north to south passing through three districts i.e. Ayah, Rowokele and Buayan. Since 1975, most people in the limestone mountain region of southern Gombong have relied their life in limestone mountain. Data from the Central Bureau of Statistics of Kebumen Regency (2014) showed that there are 130 limestone mining in limestone mountains of southern Gombong. There are 54, 39, and 37 limestone mining sites scattered in District Buayan, Rowokele and Ayah, respectively. The abandoned and unutilized open land is estimated to have reached $5 \%$ of the limestone mining area of southern Gombong.

Based on the amount of limestone mining in limestone mountains of southern Gombong, the mining is categorized into three groups. mild, moderate and heavy. Mild mining is found in Jatijajar Village, Ayah District, moderate mining in Kalisari Village, Rowokele District and 
heavy mining in Banyumudal Village, District of Buayan. Differences in mining categories (mild, moderate and heavy) may affect the diversity and productivity of indigenous forage on open land of southern Gombong limestone mountains. According to Hamidun et al. (2009), each region has a different forage diversity. Accordingly, it is necessary to study the diversity potential. A study by Gusmeroli et al. (2013) showed that the decline of forage vegetation diversity is mostly $(70 \%)$ due to ecological factors, spatial planning and management. In fact, according to Russell and Bisinger (2015), forage is so important for ruminant development, so the development of forage should necessarily consider the other ecological functions such as climate, biodiversity, as well as water and soil quality.

Based on the elaborated conditions, it is necessary to assess the diversity and productivity of indigenous forage on former limestone mining quarry as the current research related to forage in the limestone mountains to improve the development of ruminants is scarce.

\section{Materials and Method}

The study involved indigenous forage consisting of grasses, legumes and shrubs that grow naturally in limestone mountains of southern Gombong. The research location was divided into three i.e. (1) open land of former limestone mining of mild category (Jatijajar Village, Ayah District;(2) open land of former limestone mining of moderate category (Kalisari Village, Rowokele District; and (3) open land of limestone mining of heavy category (Banyumudal Village, Buayan District). The research location is presented in Figure 1.



Figure 1. Research location of the diversity and productivity of indigenous forage in former limestone mining quarry in karst mountain of southern Gombong 
The research was conducted through an onsite survey on the open land of limestone mining of southern Gombong which was purposively assigned. The samples in each of the locations were selected through $1 \times 1$ meter sample plots of quadrant system repeated five times. Parameters observed were the diversity of indigenous forage (grasses, legumes, shrubs) and indigenous forage productivity (fresh and dry matter production). Data collected, the identification and production of indigenous forage in each sample plots were then descriptively analyzed to assess the diversity and productivity of indigenous forage on the various categories of limestone mining.

\section{Results and Discussion}

\section{Geographical condition of the research}

The region of limestone mountains of southern Gombong is geographically located at $7^{\circ} 27^{\prime}-7^{\circ} 50^{\prime}$ south latitude and $109^{\circ} 22^{\prime}-109^{\circ} 50^{\prime}$ east longitude and has miocene limestone, which is hard, compact and partially coated with creamy white to pale yellow layer. Limestone mountains of southern Gombong is of cockpit type, i.e. cone-like karst hills, dense and resembling a chicken nest with a height ranging from 50-250 $\mathrm{m}$ above sea level.

Based on the physical chemical analysis, it showed that the soil texture of open land of former limestone mining of southern Gombong mountains is generally sandy loam with sand, dust, and clay contents of $52.49 \%, 34.29 \%$ and $13.22 \%$, respectively. The soil also contains about $0.621 \%$ organic matter and $6.219 \%$ calcium content. This condition shows that the soil in the former limestone mining land in limestone mountains of southern Gombong has very low organic matter but very high calcium content.

The results of chemical analysis of soil on open land of former limestone mining in various mining categories were as follows: $0.141 \%$ total nitrogen, $0.067 \%$ total $\mathrm{P}_{2} \mathrm{O}_{5}$, and
$0.095 \%$ total $\mathrm{K}_{2} \mathrm{O}$ (mild mining); $0.202 \%$ total nitrogen, $0.133 \%$ total $\mathrm{P}_{2} \mathrm{O}_{5}$, and $0.100 \%$ total $\mathrm{K}_{2} \mathrm{O}$ (moderate mining); 0,049\% total nitrogen, $0.102 \%$ total $\mathrm{P}_{2} \mathrm{O}_{5}, 0.086 \%$ total $\mathrm{K}_{2} \mathrm{O}$ (heavy mining). The study of soil fertility of the former limestone mining in various categories of mining is presented in Table 1.

Table 1. Soil fertility level of former limestone mining in the limestone mountains of southern Gombong

\begin{tabular}{lccc}
\hline Mining & $\begin{array}{c}\text { Nitrogen } \\
(\%)\end{array}$ & $\mathrm{P}_{2} \mathrm{O}_{5}(\%)$ & $\mathrm{K}_{2} \mathrm{O}(\%)$ \\
\hline Mild & 0.141 & 0.067 & 0.095 \\
Moderate & 0.202 & 0.133 & 0.100 \\
Heavy & 0.049 & 0.102 & 0.086 \\
\hline
\end{tabular}

The results showed that nitrogen and $\mathrm{K}_{2} \mathrm{O}$ content in the land of former limestone mining of heavy categories tends to be lower than those of mild and moderate mining, whereas the $\mathrm{P}_{2} \mathrm{O}_{5}$ content is relatively the same. However, the nutrient content in the mild, moderate and heavy mining is of low fertility type that may affect growth, development and productivity of indigenous forage. Hrevusova et al. (2015), stated that deficiency of nitrogen, phosphorus and potassium can affect the physical properties of soil chemistry, as well as species diversity and forage productivity. The fertilizer use of 50-200 kg nitrogen per hectare, $40 \mathrm{~kg}$ phosphorus per hectare and $100 \mathrm{~kg}$ of potassium per hectare can provide good results for a long time and it is suitable for the soil which suffers from nutrient deficiencies. The soil quality of limestone mountains can also be upgraded by planting legumes as demonstrated by Ates et al. (2014) using Medicago spp and Trifolium spp legume which have important role and high economic value to improve livestock production on less fertile land. This is because legumes can improve the quality of soil fertility and soil physical properties.

\section{Diversity of indigenous forage}

Limestone mountains of southern Gombong are generally overgrown some shade trees such 
as teak (Tectona grandis), angsana (Dalbergia latifolia), mahogany (Swietenia macrophylla), rasamala (Altingium excelsa), kalba or sengon (Albizia chinensis), johar (Senna siamea), coconut (Cocos nucifera), jackfruit (Artocarpus heterophylus), bamboo (Gigantochloa lear) and waru (Hibiscus tiliaceus). These results do not differ from that of Priyanti et al. (2011), that found six species of trees in the mountainous region of limestone of southern Gombong namely teak (Tectona grandis), rasamala (Altingium excelsa), mahogany (Swietenia macrophylla), sengon (Albizia chinensis), coconut (Cocos nucifera), and waru (Hibiscus tiliaceus). Open land of former limestone mining in limestone mountains of southern Gombong has no shade trees therefore shade level is very low and sun intensity is very high that will ultimately affect the diversity and productivity of indigenous forage. Andueza et al. (2016) stated that the diversity of botanical composition and quality of forage in the early growth is relatively stable, but on further developments it will undergo quite large change in the botanical composition and it will only be overgrown by competitive forage with high productivity and quality.

Although no trees are overgrown on open land of former limestone mining in limestone mountains of southern Gombong, the research apparently showed that some species of indigenous forage can grow and develop as presented in Table 2.

Table 2. The diversity of indigenous forage in open land of former limestone mining in limestone mountains of southern Gombong

\begin{tabular}{lccc}
\multicolumn{1}{c}{ Mining } & Grass & Legume & Shrub \\
\hline Mild & 5 & 1 & 3 \\
Moderate & 7 & 2 & 4 \\
Heavy & 4 & 1 & 2 \\
\hline
\end{tabular}

Table 2 shows that five grass species (55.5\%), one species of legume $(11.1 \%)$ and threre species (33.4\%) of shrubs are found in the open land of mild limestone mining. The five species of grass are the following: Cynodon dactylon (Kawatan), Emilia sonchifolia (Minyawon), Imperata cylindrical (reeds), Polytrias amaura (Klithi jangkrik), and Themeda arguens (Merakan). The legume species and three species of shrubs are as follows: Centrosoma pubescens (Nuts) and Ageratum conyzoides (Bandotan), Hyptis capitata (Mutmutant), Mikania micrantha (Sembung propagation), respectively. The open land of former moderate mining has the highest diversity since there are seven species of grass (53.7\%) [i.e. Cynodon dactylon (Kawatan), Eleusine indica (Welulang), Emilia sonchifolia (Minyawon), Imperata cylindrical (reeds), Polytrias amaura (Klithi jangkrik), Themeda arguens (Merakan) and Tridax procumbens (Taplekan)],two species of legumes (15.4\%) [i.e. Calopogonium (Kalopo) and Centrosoma pubescens (Nuts)], and four species of shrubs (31.9\%) [i.e. Ageratum conyzoides (Bandotan), Hyptis capitata (Mut-mutant), Mikania micrantha (Sembung rambat) and Acacia filosa (Aseman). The open land of heavy mining has seven species of indigenous forage comprising four species of grass (57.1\%) [i.e. Andropogon aciculatus (jarum-jaruman), Cynodon dactylon (Kawatan), Imperata cylindrical (reeds) and Themeda arguens (Merakan), one species of legume (14.3\%) [i.e. Centrosoma pubescens (Nuts) and two species of shrubs (28.6\%) [i.e. Hyptis capitata (Mut-mutant) and Mikania micrantha (Sembung rambat).

The study of Priyanti et al. (2011) in limestone mountains of southern Gombong discovered 12 species of forage that can be used as animal feed i.e. Commelina difusa, Eleusine indica, Eragrostis amabillis, Hyptis capitata, Imperata cylindrica and Themeda arguens. Similarly, Widodo and Wibowo (2013) in the open land surrounding limestone mining quarry in the village of Sawangan (Ajibarang, Banyumas) found 23 species of forage which are as the followings: Andropogon aciculatus, Centrosema pubescen, Chromolaena odorata, 
Commelina difusa, Elephantus scaber, Eragrostis amabillis, and Imperata cylindrica.

The diversity of indigenous forage on open land of former limestone mining in southern Gombong is relatively low compared to diversity in the natural pasture of West Papua which is relatively dry. The results of Onesimus et al. (2015) showed that there are 14 species of grass, one species of legume, and 3 other forage species, being Imperata cylindrica, Paspalum conjugatum and Ischaeum rugosum are the most dominant species.

There is a relationship between the diversity of indigenous forage on open land of former limestone mining with the soil fertility. The open land of moderate mining has the higher fertility than those of mild and heavy mining. Nevertheless, only 1-2 species of legume is overgrown in the open land of limestone mining resulting in low forage quality. Villalba et al. (2015) stated that the balance between grasses and legumes is able to increase daily body weight gain and therefore it should be paid attention to the diversity of forage species in order to increase ruminants productivity.

The research on the indigenous forage diversity is expected to be used as consideration in the development of forage to increase ruminants productivity, especially goats in the mountainous region of limestone because according to Duru et al. (2013) it is not easy to change the management of farmers on land use and type of forage to be cultivated. The change must be adapted to the soil conditions and the types of plants to be cultivated. The study of Prawiradiputra (2011) in the eruption region of Merapi volcano in which diversity and productivity of the forage have diminish showed that some types of forage remain growing i.e. Cynodon, Pennisetum and Brachiaria. Evitayani et al. (2004a) stated that dry matter digestibility of grass on rainy seasons is higher than that in dry seasons. Legume forage contained higher amounts of crude protein but lower fiber content (NDF and ADF), resulting in higher digestibility compared to grass (Evitayani et al., 2004b).

\section{Productivity of indigenous forage}

The productivity of indigenous forage is defined as the overall number of forage (grass, legumes, shrubs) produced in one hectare per year. Forage productivity is strongly determined by climate, especially drought (Washburn, 2014), spatial, ruminant population and soil fertility (Russell and Bisinger, 2015).

The results of this study showed that the productivity of indigenous forage on open land of mild mining results in the highest fresh production (8.37 ton/ha/year) compared to those of moderate and heavy mining (5.90 and 5.60 ton/ha/year), respectively as shown in Table 3. The high fresh production of the mild mining was due to the dominant species of Imperata cylindrical (reeds) and Ageratum conyzoides (Bandotan) in the region.

Table 3. Productivity of indigenous forage on former mining quarry in the limestone mountains of southern Gombong

\begin{tabular}{lcc}
\hline \multirow{2}{*}{ Mining } & \multicolumn{2}{c}{ Production (ton/ha/year) } \\
\cline { 2 - 3 } & Fresh & Dry Matter \\
\hline Mild & 8.37 & 1.59 \\
Moderate & 5.90 & 1.04 \\
Heavy & 5.60 & 1.33 \\
\hline
\end{tabular}

Results of the study also showed that the dry matter production on open land of former mild mining was the highest (1.59 ton/ha/year) compared to moderate (1.04 ton/ha/year) and heavy mining (1.33 ton/ha/year). This low dry matter production in moderate mining areas was due to the high level of diversity of indigenous forage to which each species has a different dry matter content. Indigenous forage in the moderate mining has dry matter content of $17.6 \%$, whereas the mild and heavy mining have dry matter content of around $19-23 \%$. Results of the study on open land of former limestone mining of southern Gombong were slightly different from the study of Damry (2009) conducted in the grasslands of North Lore of Poso reporting the average forage dry 
matter production of 2.1 ton/ha/year. Dismawan et al. (2014) stated that protein on grass range from $11.25-13.25 \%$ whereas herb have protein contain range from 11.61-17.14\%.

\section{Conclusions}

The soil fertility in open land of former mining in limestone mountains of southern Gombong is low with a total $\mathrm{N}$ content of $0.049-0.141 \%$, total $\mathrm{P}_{2} \mathrm{O}_{5}$ of $0.067-0.133 \%$ and total $\mathrm{K}_{2} \mathrm{O}$ of $0.086-0.100 \%$. The diversity of indigenous forage in moderate mining areas is the highest with seven species of grass, two species of legumes, and four species of shrubs, whereasmild and heavy mining comprise of 4-5 species of grass, one species of legumes and 2-3 species of shrubs. The most predominant species in all mining categories are Cynodon dactylon, Imperata cylindrica, Ageratum conyzoides and Mikania micrantha. The highest fresh and dry matter production of indigenous forage is found in mild mining (8.37 and 1.59 ton/ha/year) compared to those of moderate (5.60 -5.90 ton/ha/year) and heavy mining (1.03 - 1.33 ton/ha/year).

\section{References}

Andueza D, AM Rodrigues, F Picard, N Rossignol, R Baumont, U Cecato and A Farruggia. 2016. Relationships between botanical composition, yield and forage quality of permanent grasslands over the first growth cycle. Grass and Forage Sci. $71:$ 366-378.

Ates S, D Feindel, A El Moneim and J Ryan. 2014. Annual forage legumes in dryland agricultural systems of the West Asia and North Africa Regions : research achievements and future perspective. Grass and Forage Sci. 69: 17-31.

Bojkovski D, I Stuhec, D Kompan and M Zupan. 2014. The behavior of sheep and goats co-grazing an pastura with different types of vegetation in the karst region. J. Anim Sci. 92:2752 -2758.

Damry. 2009. Production and nutriens composition of forage produced from a natural grassland in Lore Utara. J. Agroland. 16 : $296-300$.
Dismawan IWH, IK Ginantra and NL Suriani. 2014. Selection of plant feed and nutrient content of edible plants of Bali cattle (Bos sondaicus) weaning in the south hill Badung, Badung Regency, Bali. J. Simbiosis. II:192-202

Duru M, L Hossard, G Martin and JP Theau. 2013. A methodology for characterization and analysis of plant functional composition in grassland-based farms. Grass and Forage Sci. 68 :216 - 227.

Evitayani, L Warly, A Fariani, T Ichinohe and T Fujihara. 2004a. Seasonal changes in nutritive value of some grass species in West Sumatra, Indonesia. Asian-Aust.J.Anim.Sci. 17:1663-1668.

Evitayani, L Warly, A Fariani, T Ichinohe and T Fujihara. 2004b. Study on nutritive value of tropical forages in North Sumatra, Indonesia. Asian-Aust.J.Anim.Sci. 17:1518-1523.

Gusmeroli F, GD Marianna, F Fava, A Monteiro, S Bocchi and G Parolo. 2013. Effect of ecological, landscape and management factors on plant species composition, biodiversity and forage value ain Alpine meadows. Grass and Forage Sci. 68: 437-447.

Hamidun MS, D Wahyudi, K Baderan, I Saragih and NK Taro, 2009. Potential of Different three pastures in Manokwari Regency. Jurnal IImu Peternakan 4 : 53-60 (In Indonesia).

Hrevušová Z, M Hejcman, J Hakl and J Mrkvička. 2015. Soil chemical properties, plant species composition, herbage quality, production and nutrient uptake of an alluvial meadow after 45 years of N, P and K application. Grass and Forage Sci. 70:205-218.

Onesimus Y, A Supriyantono, T Widayanti and I Sumpe. 2015. Botanical composition and distribution of forage of natural pasture in West Papua. Pastura. 4 : 62 - 65. (In Indonesia).

Priyanti, F Wijayanti and M Rizki. 2011. Diversity and potential of flora in Karst Mountain of Gombong, Central Java. Berkala Penelit. Hayati Edisi Khusus. 5A :79-81. (In Indonesia).

Russell JR and JJ Bisinger. 2015. Forages and Pastures Symposium : Improving soil health and productivity on grasslands using managed grazing of livestock. J. Anim Sci.93 : 2626 2640.

Villalba JJ, R Cabassu and S A Gunter. 2014. Forage choice in pasturelands: Influence on cattle foraging behavior and performance. J. Anim Sci. 93:1729-1740.

Washburn SP. 2014. Forages and Pastures Symposium: Forage systems adaptable to dry conditions. J. Anim Sci. 92: 2809-2810.

Widodo P and N Wibowo. 2013. Monitoring of Low Plants in Limestone Mining in Sawangan Village, Ajibarang District, Banyumas Regency. The Faculty of Biology, Jenderal Soedirman University. Purwokerto. (In Indonesia). 